\title{
USE OF QUANTITATIVE CRITERIA IN THE MANAGEMENT OF PERSONAL CONSUMPTION EXPENDITURE: CHALLENGES AND OPPORTUNITIES
}

\author{
Kamilè TAUJANSKAITÉ ${ }^{1}$, Eugenijus MILČIUS' ${ }^{2}$, \\ Nomeda DOBROVOLSKIEN $\dot{E}^{3}$
}

\author{
${ }^{1,3}$ Department of Finance Engineering, Faculty of Business Management, Vilnius Gediminas \\ Technical University, Sauletekio al.11, LT-10223, Vilnius, Lithuania \\ ${ }^{2}$ Centre of Packaging, Innovation and Research, Faculty of Mechanical Engineering and \\ Design, Kaunas University of Technology, K. Donelaičio g. 73, LT-44249, Kaunas, Lithuania \\ E-mails: ${ }^{1}$ kamile.taujanskaite@vgtu.lt (correspondingauthor); ${ }^{2}$ eugenijus.milcius@ktu.lt; \\ 3nomeda.dobrovolskiene@vgtu.lt
}

Received 07 March 2017; accepted 03 May 2017

\begin{abstract}
Various non-economic factors, like social, cultural, psychologic and others strongly affect the decision-making related to the management of personal consumption expenditure (PCE) in households and often compromise its efficiency. PCE management tools and methods currently used by households are not helpful either as rational distribution of funds among the purchases is usually out of their scope. Therefore, rational use of resources still remains a challenging task for many households. The goal of this study is to analyse the PCE management process in households and the obstacles preventing its efficiency. Methods used in the article comprise: comparative and critical analysis methods; vector analysis tools. The paper identifies shortcomings of currently used PCE management methods and tools and introduces a system of quantitative criteria enabling objective evaluation of consumption alternatives. The use of quantitative criteria limits the influence of subjective, non-economic factors on consumption-related resource management in households and can positively affect its efficiency. The criteria are justified theoretically and the benefits from their use demonstrated with some practical evidence.
\end{abstract}

Keywords: household, household economics, consumption expenditure, individual assetliability management, household budget, consumption-related decision making.

JEL Classification: B16, B21, C51, C69, C81, D12, D19.

\section{Introduction}

Personal consumption expenditure (PCE) accounts for approximately $2 / 3$ of Lithuania's gross domestic product (GDP). This share is comparable to the average of many other countries around the world (World Bank 2016). Only due to its volume, the consumption-related monetary flow produced by households is so important for the economic system of every country. It is the primary engine that drives future economic growth and determines business conditions for virtually any economic entity, regardless of what 
segment it operates in: manufacture, services, retail banking or other, therefore has attracted attention of numerous researchers (Kyrk 1923; Friedman 1957; Becker 1960; Lancaster 1966; Engel et al. 1968; Deaton 1992; Pollak 2002; Bray 2008; Connoly, Prothero 2008; Dean 2009; Parker 2010; Czech 2012; Brohmann, Quack 2015, QuintanaDomeque, Wohlfart 2016; Ganong, Noel 2016; Zhao et al. 2016; Hardardottir 2017).

Several PCE parameters are of key importance for the economy. While the aggregate country-wide volume is the main factor to determine macroeconomic indicators (e.g. the supply-demand balance), the parameters characterising efficiency of its management in households, instead, determine the budgetary performance of every household and the performance of financial institutions, which have business relations to them. Therefore, the parameters characterising management efficiency on the household level are as important as the aggregate volume.

Up to $40 \%$ of households in Lithuania are unable to maintain control of their budgets (Bank of Lithuania 2015), which indicates serious resource management problems specifically at this level. Poor borrower performance of households is another aftermath of inefficient management of their resources. The non-performing retail loans (NPL) in Lithuania in 2015 amounted to 5.5\% (Bank of Lithuania 2016). Although this level was significantly lower than the highest rate of over $20 \%$ reached in 2010 , it still remained several times higher than the pre-crisis level of $1-2 \%$ in 2007-2008. This condition of the loan portfolios resulted in a significant loss for commercial banks, which afterwards took approximately five years to fully recover.

The same problems are important not only for Lithuania but for the economies and banking systems of many other countries. For example, in 2015 the NPL level in Italy was $17.3 \%$, in Ireland $18.8 \%$, in Greece $34.4 \%$ and even $44.8 \%$ in Cyprus (World Bank 2016). The value of NPL portfolio in Italy made 200 billion EUR in 2015, while the total NPL value in the European Union (EU) is estimated to be close to 1 trillion EUR, or about $7 \%$ of its aggregate GDP.

The increase of NPL level is traditionally linked with economic turndowns, but researches of individual households not always support this opinion. Households from low income segment often demonstrate better borrower performance and efficiency in managing own budgets than wealthier households (Taujanskaitè, Milčius 2012; AlvarezCuadrado, Japaridze 2017). Inability of some households to timely adapt to the changing economic environment and adjust their consumption accordingly is one of the reasons to cause such situation. Consumers tend to fix firmly to the consumption pattern they are accustomed to and are reluctant to change it. Influence of factors, especially those having psychological background, compromise economic logics related to household's financial decision-making. As a result, this process becomes very complex and diverse, budget constrains are often ignored, which leads to complete loss of its control. Various newly emerged consumption patterns, like green consumption, sustainable consumption or humanistic (Bray 2008; Connoly, Prothero 2008; Brohmann, Quack 2015) are especially liberal in this sense, therefore a number of consumers who follow certain consumer ideas without paying due attention to availability of resources is expected to further increase. 
According to the Bank of Lithuania (2015), even $88 \%$ of Lithuanian population indicate that they make financial decisions based on their own experience, the opinion of people they know or trust, or information collected from media, including TV and Internet. The relevance and trustworthiness of such information and the motivation of financial decisions based on them are questionable; therefore, it is not surprising that so many households face financial and budget management problems. Management efficiency could improve if decisions made by households were based only on objective and quantifiable criteria. From this point of view, the application of special formalised decision-making procedures eliminating the interference of subjective, non-economic motives, should be especially beneficial.

The paper introduces a formalised, quantitative criteria-based approach to the PCE management, which specifically targets the allocation of household's financial resources for goods and/or services prior to their purchase. The approach aims at eliminating or at least limiting the influence of subjective, non-economic factors on decision-making. The paper justifies its use theoretically and supports with some practical evidence.

Section one of the paper presents overview of methods and tools currently used by households for the management of personal consumption expenditure (PCE). In section two the factors determining consumption-related decision-making in households are analysed. In section three an alternative, value decomposition-based view on PCE management and a system of quantitative evaluation criteria of consumption alternatives are introduced. Section four analyses aspects of practical application of introduced approach for evaluation of consumption alternatives and provides some examples.

Methods applied in the research comprise comparative and critical analysis and vector analysis tools.

\section{Models and tools used for financial resource management in households}

Finance management models used by households target different tasks. Maintaining an optimal balance of assets that ensures that all household's liabilities are met and financial goals achieved, is one of them. In the research this domain is known as asset and liability management (ALM) and has seen tremendous recognition and growth during the last decades (Ziemba, Mulvey 1998). The primary application areas of ALM are pension plans, insurance companies, banks, university endowments and individual investors (Hocht et al. 2008).

Individual Asset-Liability Management model (iALM) (Dempster, Medova 2011) is intended for life-long financial decision-making in households and, particularly, for development the retirement plans. The model is based on the use of two principles: a) individual wealth is measured by sustainable spending over a household's life time; and b) individual risk attitude at any point in time is a reflection of existing and foreseen liabilities together with a subjective view of desirable personal future consumption. Model employs Monte Carlo simulation, discrete or continuous dynamic programing and dynamic stochastic programming. 
Dynamic Model for Individual Asset Liability Management is used as a support tool, which offers more than one financial plan to the household for consideration based on subjective opinion regarding future life events. The difference between inflows and outflows gives the net increase in a household's financial wealth in a given year. The risk characteristics of the evolution of optimal portfolios depend on asset return volatilities, their correlations and the risk management constraints of the portfolio models. These constraints, set according to individual household preferences, impose a tolerable annual drawdown of the portfolio in each of these scenarios over the household's lifetime. The model is a pure finance planning and management tool and consumption expenditure (PCE) management is out of its scope.

Hybrid Model for Optimal Decisions within Personal Finance and Retirement (Konicz 2012). The model covers two cases of application: Case A deals with optimal investment, consumption and life insurance; and Case B with optimal investment with optimal annuities. The model is not applicable to PCE management.

Financial Planning for Young Households: Multi-stage Stochastic Programming Model (Pedersen et al. 2013). Analyses the financial planning problems of young households whose main decisions regard the ability to finance the purchase of a house (liabilities) and allocation of investments into pension savings schemes (assets).

Personal Asset Allocation Model (Consiglio et al. 2002, 2007). The system of Personal Financial Tools (PFT) provides support for each one of the goals facing a typical family, thus extending the work of Financial Engines, but it does so by segmenting the family's planning problem into distinct sub-goals.

The analysed models are first of all intended for allocation of financial resources for either a certain period of the life-cycle, or cover all the person's life, but not applicable to the planning of everyday consumption expenditure and not detailed to the level to cover every elementary purchase.

Another group of financial resource management tools found in the market are specifically intended for the control of households' budget (see Table 1).

The budget plan built by using this software enables organizing household's cash flow, expenses and usually the bank accounts in one place. Charts and graphs, which visualize monetary flows and statistics, show data from month-to-month. This information enables a person to track his or her progress, discover where he or she can make savings and improve the money management process. The main shortage of these tools is that they can only be used for registration of expenditure and the follow-up on cash flow, but do not provide for the possibility to optimise the allocation of funds. No formal analysis and evaluation of the utility gained with each individual unit of purchased good is possible and no objective information is available for the current budget design except of experience from the previous budget planning periods.

Models dedicated specifically for asset allocation and management of funds, like Prospero Asset Management Software (Sage 2016), Personal Capital, Quicken, Betterment, Scottrade, Tradeking, TD Ameritrade, E*Trade, Capital One ShareBuilder and Acorns (Rose 2016) represent a separate group. 
Table 1. Most popular budgeting tools for households

\begin{tabular}{llll}
\hline & Practical Tools for Household Finance Management \\
\hline You Need a Budget (YNAB) & Fudget & Mvelopes & Personal Budgeter \\
Mint & Goodbudget & Money Tracker & Personal Wallet Manager \\
Buxfer & LearnVest & Bank Tree & Personal Accounting \\
Geezeo & Level Money & Neo Budget & Personal Finance Planner \\
BudgetPulse & Penny & Money Weil & Personal Financial Record \\
Gnu Cash & Personal Capital & Simple Budgeting & Personal Finance Report \\
Budget Simple & Wallaby & Budget Planner & Personal Finance Helper \\
Wallet & Money Manager Ex & Money Plus Deluxe & Star Money 8.0 \\
Spendbook & Simple Accounting & Mano finansai & Money Me \\
Home Budget with Sync & My Micro Balance & Daily Expenses & Expense Online \\
Level Money & Money Dance & Money Book & Armory 0.87 \\
BUDGT & Butas & Spendle & Ace Money \\
Spendee & Namu Buhalteris & Manilla & Kur dingo pinigai? \\
Expensify & Quicken Deluxe 2014 & Check & Easy Money \\
MoneyDance & Expense IQ & Expensify & Microsoft Money \\
Moneystrands & Expense Notes & Level Money & Home Bank \\
Pocketsmith & Good Budget & BankPlus Persona Mobile & Bank Tree Personal \\
Yodlee & Money Dash Board & Splash Money & Simple Home Money Management \\
Consur & Love Money & Personal Finance Manager Lite & Rich or Poor \\
BillGuard & Clear CheckBook & Easy Finance Personal & Budget Express \\
Dollarbird & My Spending Plan & One Money & MS Dynamics nav. \\
\hline & & & \\
\hline
\end{tabular}

Sources: created by authors according to Sharf 2016; Corpuz 2015; Henry 2014; Crary 2012; Herdrich 2008.

Besides, a number of other specialised programs exist, among them, Ready for Zero and Credit Sesame, which are debt reduction software, Credit Karma - a credit monitoring software tool and Turbo Tax - a tax software tool (Rose 2012), and other.

Figure 1 classifies the observed methods and tools by their purpose. Performed analysis shows that although the market is relatively saturated with various models, none of them can help the consumer with rational distribution of funds among goods/services

\begin{tabular}{|c|c|c|}
\hline \multicolumn{3}{|c|}{ Models for household finance management process } \\
\hline $\begin{array}{c}\text { I. Static models for incoming } \\
\text { and outgoing financial flows } \\
\text { registration }\end{array}$ & $\begin{array}{c}\text { II. Dynamic models for } \\
\text { investment decisions } \\
\text { optimization }\end{array}$ & $\begin{array}{c}\text { III. Dynamic models for } \\
\text { asset-liabilities } \\
\text { management }\end{array}$ \\
\hline \multicolumn{3}{|c|}{ What is missing? } \\
\hline Lack of tools for the management of financial processes on the elementary \\
purchase level
\end{tabular}

Fig. 1. Summary on methods and tools used for household finance management 
prior to the purchase. As total consumption budget of the household is composed of elementary purchases, the proper allocation of funds is of key importance for efficient budget management. Benefits from using models without this feature are limited and their enhancement by integrating tools, which enable the distribution of funds for purchases based on objective criteria, should open new possibilities in budget management. Further analysis aims at developing tools, which would help to fill the existing gap.

\section{Issues with rational allocation of funds in consumption expenditure management}

Various factor groups, like psychological, personal, social, cultural, environmental and other affect the consumption-related decision-making in households (see Fig. 2).

The research of behaviour of various consumers has revealed a number of typical behaviour patterns depending on the prevailing motives, which shape them. Several classification schemes have been built as a result of this research.

Classification of consumer types by social classes comprise: upper-upper $(0.5 \%$ of the population), lower-upper (2\%), upper-middle (10\%), lower-middle (35\%), upper-lower (40\%), lower-lower (12\%) (Smith 1964).

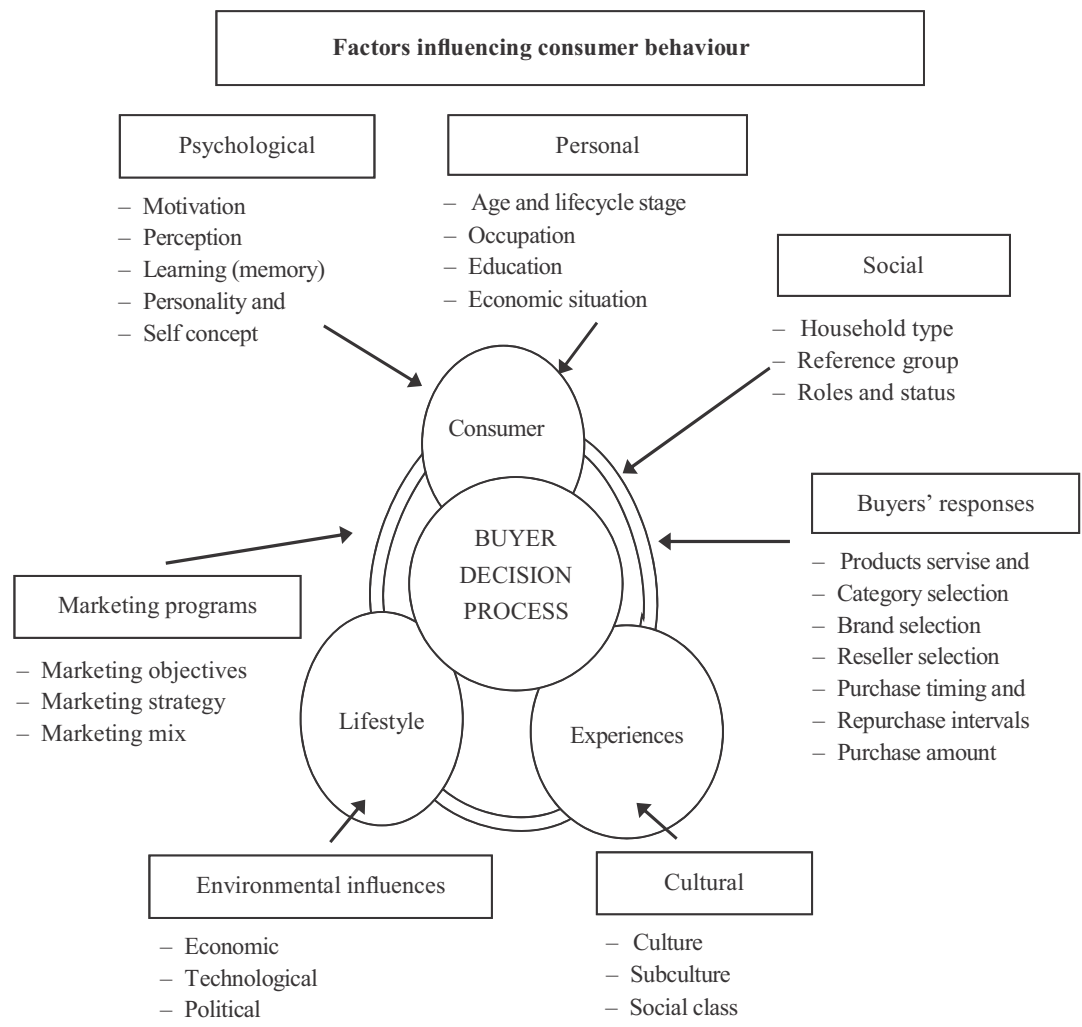

Fig. 2. Main factors that influence consumer behaviour (Consumer Voice Organization 2012) 
Various psychological approaches have been applied (Bray 2008), which resulted in different typological classifications with five major approaches emerging (Foxall 1990): Economic Man. Early research regarded man as entirely rational, making decisions based upon the ability to maximise utility whilst expending the minimum effort. While work in this area began around 300 years ago (Richarme 2005), the term "economic man" (or Homo economicus [Persky 1995]) was first used in the late 19th century (Persky 1995). Later research and theories developed by, e.g. Herbert Simon (satisficing theory) or Kahneman and Tversky's prospect theory (Simon 1997; Kahneman, Tversky 1979) have proved that such behaviour in reality cannot exist simply because of the lack of objective information needed to guide it. Psychodynamic. The psychodynamic tradition within psychology is widely attributed to the work of Sigmund Freud (Stewart 1994). The key tenet of the psychodynamic approach is that behaviour is determined by biological drives, rather than individual cognition or environmental stimuli (Howard, Sheth 1969; Bray 2008; Arnold et al. 2010). Behaviourist. Essentially behaviourism is a family of philosophies stating that behaviour is explained by external events. The causation of behaviour is attributed to factors external to the individual (Bray 2008). Cognitive. In contrast to the foundations of classical behaviouralism, the cognitive approach ascribes observed action (behaviour) to intrapersonal cognition. The individual is viewed as an "information processor" (Ribeaux, Poppleton 1978). Humanistic. The humanistic approach uses behaviour motives, which are beyond those, which actually make ground for Economic Man's behaviour based on purely egoistic motives.

Euromonitor International (2015) has recently presented another classification, which comprise: Undaunted Striver. Consumer looks for new and innovative products, wants to dominate in society. Likes luxury and exclusive things. Impulsive Spender. Buying decisions depend on emotions, the consumer is advertising sensitive. Conservative Homebody. Prefers well-known products, rarely buys novelties. Does not want to dominate in society. Aspiring Struggler. Looks for something that could make him unique and idiosyncratic. Appreciates prestige and well-known brands. Independent Skeptic. Typically, self-confident, not advertising sensitive. Likes high quality purchases. Before buying, analyses all product features. Secure Traditionalist. Buys tested items, does not pay attention to new products. Likes stability and traditions. Balanced Optimist. Makes buying decisions rationally, likes tested items, but does not exclude innovations.

In addition, a number of new consumption types have emerged recently, among them Sustainable consumption - ways of consumption that reduce environmental stress and meet the basic needs of humanity (Hertwich et al. 2015; Bertrand, Morse 2016), Green consumption - a concept that ascribes to consumers the responsibility or co-responsibility for addressing environmental problems through adoption of environmentally friendly behaviours, (Connoly, Prothero 2008; Elliott 2013), Smart consumption - consumption that creates a prosperous world while using fewer resources or buying something with a view to sustainable benefits (Brohmann Quack 2015), Connected consumers - evolving consumer behaviour in light of modern communication technologies (Oracle 2012).

Behaviour within any of the mentioned social classes or other consumer groups is quite mixed, not homogeneous, which makes it even more difficult to understand the logics 
behind buying decisions. Therefore, efforts by, e.g. Engel, Blackwell, Kollat and others to develop systemic models of the consumer buying decision process (or decision making tree) were not successful so far (Bray 2008).

This illustrates the complexity and difficulties within the consumer decision-making and explains why funding of purchases is often spontaneous and budget restraints are ignored. Obviously, no rational use of resources is possible without criteria enabling objective, preferably quantitative evaluation of every good or service before the purchase.

\section{Quantification of decision-making criteria by using value decomposition of goods and services}

The household expenditure management problem is interpeted by economic theories as finding an optimal ratio between funds allocated for current-time consumption and the savings to provide for maximal life-long utility. From the mathematical point of view, the problem is usually presented in a following way (Sniedovich 2010; Dasgupta et al. 2006; Denardo 2003):

subject to:

$$
\max \sum_{t=0}^{T} b^{t} \ln \left(c_{t}\right)
$$

$$
k_{t+1}=A k_{t}^{a}-c_{t} \geq 0,
$$

for all $t=0,1,2, \ldots, T$, where $T$ is the expected lifetime of the consumer, $c_{t}$ is consumption in period $t$, which yields utility

$$
u\left(c_{t}\right)=\ln \left(c_{t}\right),
$$

$b^{t}$ is a factor, which discounts future utility, $k_{t}$ is a capital in period $t$. The next period's capital $k_{t+1}$ is determined by this period's capital and current consumption:

$$
k_{t+1}=A k_{t}^{a}-c_{t},
$$

where $\mathrm{A}$ is a positive constant and $0<\mathrm{a}<1$.

Solution of the problem for all the variables $c_{0}, c_{1}, c_{2}, \ldots, c_{T}$ and $k_{1}, k_{2}, k_{3}, \ldots, k_{T+1}$ initially looks complicated, but by applying certain methods, like dynamic programming, it can be significantly simplified.

If distribution of households resources can be optimised by using relatively simple mathematical tools, why do so many households, irrespective of income level, experience difficulties not only with accumulating sufficient savings, but even trying to keep their current budgets balanced? This problem has been specifically analysed in Taujanskaite and Milčius (2015) and revealed several reasons, which make the problem much more complicated than it might initially look.

The problem as presented above uses the expression of utility from current consumption in the form of function $u\left(c_{t}\right)=\ln \left(c_{t}\right)$, which represents an aggregate utility of the period. As real aggregate utility $u\left(c_{t}\right)$ is being composed of every single financial transaction, the consumer should repeat the above procedure every time he pays for goods, including 
the allocation of funds for this transaction and maximising utility from it in the context of the rest needs of the period. As a result, a simple optimisation in reality turns into a multi-objective.

As it follows from the previous analysis, the decision whether or not to buy a specific good depends on its features and especially on how they are perceived by the consumer subject to his psychological condition (Freud 1904; Maslow 1954). The utility of every good is complex (Lancaster 1966); therefore, the optimisation problem is not only multiobjective, but also multi-attribute.

Besides, manufacturers and sellers invest in marketing huge resources trying to change consumer behaviour. This strongly affects decision-making and turns it into a purely psychological task having no or almost no relation with economic rationale. As a result, the consumer's real problem becomes very complicated and it is not surprising that budget management becomes problematic for so many households.

Multi-criteria evaluation methods, which are increasingly used in recent years (Ginevičius, Podvezko 2007, 2008), could be applied for this purpose, but solving the problem every time an elementary purchase is being made (many times a day!) by using such tools would not be acceptable for the consumer from the practical point of view.

The biggest problem when analysing the consumer decisions comes from the fact that evaluation of any good is very personal and produces a number of evaluation (utility) scores, which almost equals the number of consumers. This makes the utility-based systemic view on the consumer buying decisions problematic. In Taujanskaite and Milčius (2015) an attempt was made to bypass this problem by developing an approach, which reduces the number of evaluation criteria. The approach comprises a two-stage evaluation process and uses as a base the value of the good instead of its utility. At first stage, the good is given an aggregate value score, equal to its market price, which afterwards is decomposed by applying the Maslow hierarchy of needs theory. Decomposition of aggregate value produces a number of its components, which equals the number of hierarchy levels in the Maslow's pyramid of needs. Each value component represents a specific level of needs in the pyramid and has fixed magnitude, which expresses the capacity of the good to satisfy them, while vector sum of all components gives the aggregate value of the good. The main advantage of the approach is that a huge variety of evaluation scores of the good in this case is expressed by a limited number of components. The magnitudes of aggregate and the component values are fixed, universal and irrelevant to the opinion of the consumer. The second, or matchmaking stage is used to select a proper good from available alternatives by matchmaking it with the consumer's needs in accordance to his/her specific preferences.

As stated, the aggregate value $V$ of the good or service is complex and is composed of virtual value components $V_{n}$ :

$$
\bar{V}=\sum_{i=1}^{n} \overline{V_{i}},
$$

where $\bar{V}$ and $\bar{V}_{t}$ are vectors in a ' $n$ ' coordinate space. ' $n$ ' is a number of levels in the Maslow pyramid of needs. 
Presume, the market price of the good/service $P_{m}$ is determined by the magnitude of its aggregate value vector $|\bar{V}|$, i.e.

$$
P_{m} \equiv|\bar{V}| .
$$

As a consumer not necessarily needs all the good features (value components), there is always a risk that the aggregate value might be higher than the utility brought by them to the specific consumer. The only exception does exist when the utility is equal to the aggregate value, which happens in the case when value $\bar{V}$ and the utility $\bar{U}$ vectors are collinear in reference to the applied " $n$ " dimensional coordinate space.

Therefore, consumer almost always, except of some cases, is about to pay higher than needed price for the goods he purchases (Taujanskaite et al. 2015). This is because the sellers expect to get full price, which corresponds the aggregate value. A rational consumer not only should check the content of value components, but also the proportions between their magnitudes. Only this can guarantee that the price composition would correspond to the utility sought by the consumer. An aggregate price of the good in this case would match its utility $\bar{U}$ :

$$
P_{u} \equiv|\bar{U}|
$$

As

$$
\bar{U} \leq \bar{V}
$$

consequently $P_{u} \leq P_{m}$.

By comparing the aggregate price of the good we are interested in with the price of an alternative good with the same purpose, but containing only the basic value (corresponds to physiological needs level in the pyramid), we can guide the purchase process so that buying decisions are based on objective, quantitative information about the cost of additional value we appreciate.

\section{Relationship between the aggregate value and its components}

Let's say we analyse a case, where the number " $n$ " of levels in Maslow pyramid of needs is reduced down to 3 and represents basic, comfort and prestige needs of the consumer. The magnitude of aggregate value vector $\bar{V}$ when its basic $\overline{V_{b}}$, comfort $\overline{V_{c}}$ and prestige $\overline{V_{p}}$ components:

$$
|\bar{V}|=V ;\left|\overline{V_{b}}\right|=V_{b} ;\left|\overline{V_{c}}\right|=V_{c} ;\left|\overline{V_{p}}\right|=V_{p},
$$

are known, can be calculated by using formula:

$$
V=\left(V_{b}^{2}+V_{c}^{2}+V_{p}^{2}\right)^{0,5} .
$$

If component values are unknown, they can be calculated based on assumption that direct relationship exists between the aggregate value of the good and its price $P_{m} \equiv|\bar{V}|$. By retrieving certain market prices and combining them with the following system of equations: 


$$
\left\{\begin{array}{l}
V_{c}=\left(V^{2}-V_{b}^{2}-V_{p}^{2}\right)^{0,5} \\
V_{p}=\left(V^{2}-V_{b}^{2}-V_{c}^{2}\right)^{0,5} \\
V_{b}=\left(V^{2}-V_{c}^{2}-V_{p}^{2}\right)^{0,5}
\end{array}\right.
$$

we can calculate unknown $V_{b} ; V_{c}$ and $V_{p}$.

As we have a system of three equations with three unknown, at least three targeted market price tests should be performed to calculate them. First, a cheapest alternative of the good, which satisfies only the basic (physiologic) needs of the consumer, is found. This alternative contains no comfort and prestige components therefore they have zero value. $V_{b}$ is equal to the market price of that alternative. By choosing another alternative, which contains more value, but is not of luxury category, we can find the magnitude of its comfort component $V_{c}$ assuming that basic value remains the same as previous. Any other alternative of the good with higher price would contain prestige component and its magnitude can be calculated by using the $V_{p}$ equation with $V_{b}$ and $V_{c}$ values from the previous calculations.

If the vector of preferences of the consumer is used to guide the purchase process, than the magnitudes of basic, comfort and prestige vectors are supposed to be known. In this case information about their shares in the aggregate preference value is important. These shares can be calculated by using following expressions:

$$
\begin{gathered}
b_{v}=b^{*} \cos \alpha^{*} \cos \psi \\
c_{v}=c^{*} \sin \alpha^{*} \sin \psi \\
p_{v}=p^{*} \sin \psi
\end{gathered}
$$

where:

$$
\begin{gathered}
\alpha=\operatorname{arctg} \frac{c}{b} \\
\psi=\operatorname{arctg} \frac{p}{b \cos \alpha+c \sin \alpha}
\end{gathered}
$$

\section{Compatibility of purchases with the consumer preferences}

The collinearity of vectors $\bar{V}$ and $\bar{U}$ and equality of their magnitudes means maximum available utility produced by the aggregate value $V$ as only in this case the value vector $\bar{V}$ contains components, which exactly match the consumer's needs in terms of both the content and the required proportions between them in reference to the axis representing the value components. The worst case is when angle between the two vectors is approaching $90^{\circ}$, meaning that consumer's utility from the purchase makes only a tiny fraction from the aggregate value and turns zero when the angle is equal to $90^{\circ}$. Therefore, it is important for the rational consumer to always know, how the vectors $\bar{V}$ and consumer's preference vector $\bar{U}_{p}$ are mutually oriented in the " $n$ " dimensional 
space of preferences. An angle $\varphi$ between the two vectors in the case of $n=3$ can be calculated in the following way.

Let's say the consumer's preference vector is:

$$
\bar{U}_{p}=\lambda * \bar{b}+\mu * \bar{c}+\mathrm{v} * \bar{p}
$$

and the aggregate value vector $\bar{V}$ is:

$$
\bar{V}=\overline{V_{b}}+\overline{V_{c}}+\overline{V_{p}} \text {. }
$$

Note. Utility vector $\bar{U}$ of the good is a projection of vector $\bar{V}$ on the vector of preferences $\bar{U}_{p}$.

The aggregate value vector $\bar{V}$ and utility preference vector $\bar{U}_{p}$ make an angle $\varphi$. If $\varphi$ is $0^{\circ}$, than vectors $\bar{V}$ and $\bar{U}_{p}$ are collinear, which means that the aggregate value of the good exactly matches the consumer's preferences.

Calculating $\varphi$ :

$$
\begin{gathered}
\bar{U}_{p} * \bar{V}=\left|\bar{U}_{p}\right| *|\bar{V}| * \cos \varphi \\
|\bar{b}|=|\bar{c}|=|\bar{p}|=1
\end{gathered}
$$

then:

$$
\bar{U}_{p} * \bar{V}=U_{p b} * V_{b}+U_{p c} * V_{c}+U_{p p} * V_{p}=\lambda * V_{b}+\mu * V_{c}+v * V_{p} .
$$

Taking into account (9) and (10) and that the magnitude of $\bar{U}_{p}$ is:

$$
\left|\bar{U}_{p}\right|=\sqrt{(\lambda * b)^{2}+(\mu * c)^{2}+\left(v^{*} p\right)^{2}} .
$$

We get:

$$
\begin{gathered}
\cos \varphi=\frac{\lambda * V_{b}+\mu * V_{c}+v^{*} V_{p}}{\left|\overline{U_{p}}\right| *|\bar{V}|} ; \\
\varphi=\arccos \frac{\lambda * V_{x}+\mu * V_{y}+v^{*} V_{z}}{\left|\overline{U_{p}}\right| *|\bar{V}|} .
\end{gathered}
$$

Figure 3 illustrates the range of angle $\varphi$ variation at changing preferences of the consumer (consumption patterns) and various consumption options. The segment of nourishment has been analysed and the following options compared: 1 - self-made food from basic products, 2 - semi-fabricated, frozen, 3 - semi-fabricated, fresh, 4 - canteen, 5 - cafeteria, 6 - ordinary restaurant, 7 - high-class restaurant.

The presented graphs show that consumption pattern, which prefers the basic value $(\lambda=$ $3 ; \mu=0 ; v=0)$, is not compatible with dining in restaurants and even canteens as angle $\varphi$ in this case reaches 70-90 degrees and, vice-versa, when the consumer prefers prestige and luxury $(\lambda=1 ; \mu=0 ; \nu=5)$, only alternatives 5-7 are likely to satisfy him or her. A case study within nourishment has been performed to illustrate the value decomposition procedure. The price of the same dish, having same nutrition value (kilocalories) has been measured by comparing the above mentioned nourishment alternatives. 


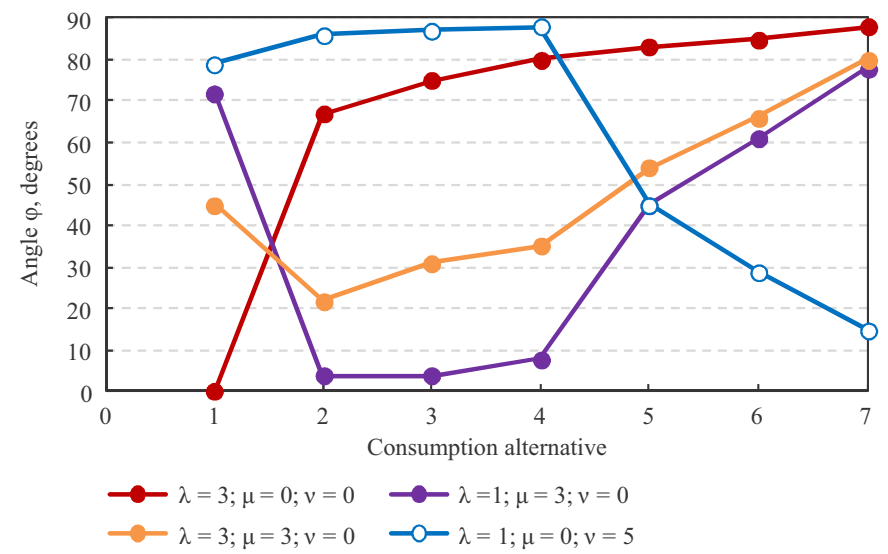

Fig. 3. Angle $\varphi$ between consumer's preference vector and the aggregate value vector of goods in focus

The $\mathrm{n}=3$ decomposition was used to split the aggregate value (price) into basic, comfort and prestige components and find their quantitative scores. As nutrition value in all cases is the same, the alternative (1) was considered to represent the basic value, while alternatives 2, 3 and 4 besides the basic value also contain different amounts of comfort and, finally, alternatives 5, 6 and 7 additionally to include different amounts of prestige (luxury). All the alternatives have different aggregate prices per $100 \mathrm{~g}$ of the product and so the prices per kilocalorie (see Table 2). The price of the dish and its aggregate value strongly depend on nourishment type and can differ many times. In this case the difference reaches 25 times indicating of significant saving potential if consumption alternative is carefully selected.

Table 2. Effect of value components on aggregate price of the dish having same nutritional value

\begin{tabular}{|c|c|c|c|c|c|c|c|c|}
\hline & \multirow{2}{*}{$\begin{array}{l}\text { Nourishment } \\
\text { alternative }\end{array}$} & \multirow{2}{*}{$\begin{array}{l}\text { Product } \\
\text { price } \\
\text { EUR/100g }\end{array}$} & \multirow{2}{*}{$\begin{array}{l}\text { Price per } \\
\text { kilocalorie, } \\
\text { cents }\end{array}$} & \multicolumn{4}{|c|}{ Value per kilocalorie, cents } & \multirow{2}{*}{$\begin{array}{c}\text { Price per } \\
\text { kilocalorie, } \\
\text { Relative units }\end{array}$} \\
\hline & & & & Basic & Comfort & Prestige & Aggregate & \\
\hline 1 & $\begin{array}{l}\text { Basic } \\
\text { products }\end{array}$ & 0.16 & 0.07 & 0.07 & 0.00 & 0.00 & 0.07 & 1.00 \\
\hline 2 & $\begin{array}{l}\text { Semi- } \\
\text { fabricated } \\
\text { frozen }\end{array}$ & 0.41 & 0.18 & 0.07 & 0.17 & 0.00 & 0.18 & 2.56 \\
\hline 3 & $\begin{array}{l}\text { Semi- } \\
\text { fabricated } \\
\text { fresh }\end{array}$ & 0.63 & 0.28 & 0.07 & 0.27 & 0.00 & 0.28 & 3.98 \\
\hline 4 & Canteen & 0.89 & 0.39 & 0.07 & 0.38 & 0.00 & 0.39 & 5.56 \\
\hline 5 & Cafeteria & 1.23 & 0.54 & 0.07 & 0.38 & 0.37 & 0.54 & 7.71 \\
\hline 6 & $\begin{array}{l}\text { Restaurant } \\
\text { ordinary }\end{array}$ & 1.82 & 0.80 & 0.07 & 0.38 & 0.70 & 0.80 & 11.40 \\
\hline 7 & $\begin{array}{l}\text { Restaurant } \\
\text { upper class }\end{array}$ & 4.05 & 1.79 & 0.07 & 0.38 & 1.74 & 1.79 & 25.45 \\
\hline
\end{tabular}




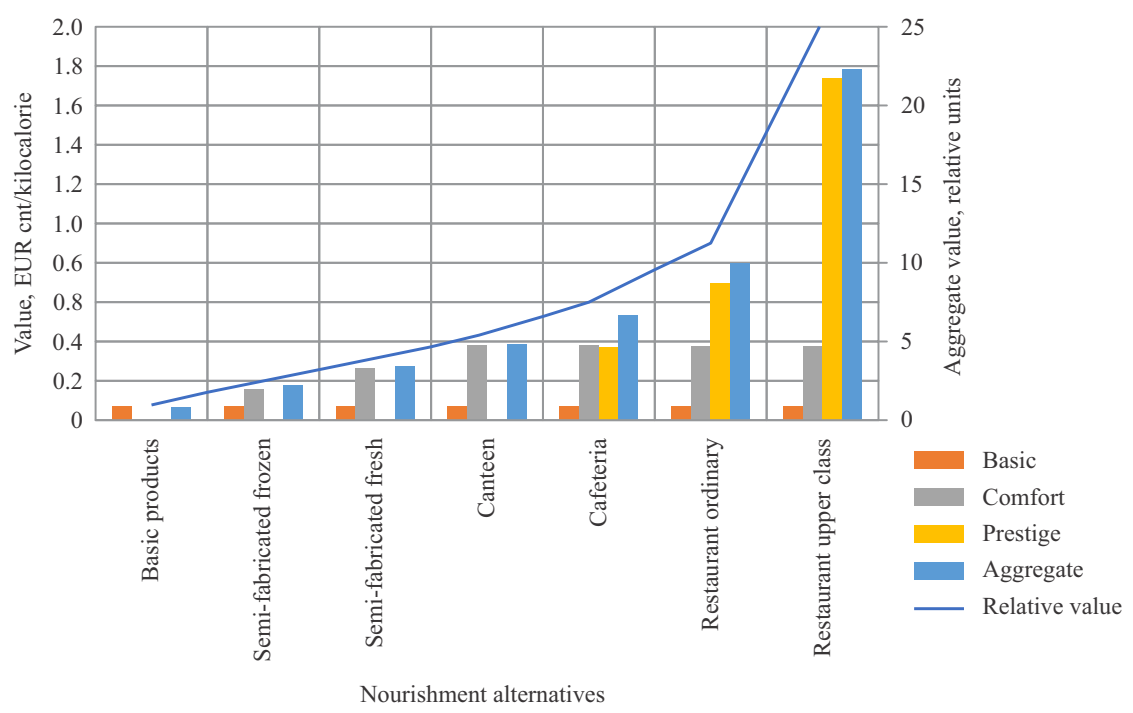

Fig. 4. Influence of nourishment type on the kilocalorie price of the same dish

The same results are displayed in Figure 4.

The results confirm that application of value decomposition enables refinement and quantification of value components as well as objective evaluation and comparison of consumption alternatives. They also demonstrate significant saving potential, which quantitative value components $V_{b} ; V_{c}$ and $V_{p}$. of goods could provide if used as the household expenditure management tools.

\section{Conclusions}

The volume of personal consumption expenditure (PCE) and efficiency of its management are the main factors that determine performance of country's economy on both micro- and macro levels. Efficient PCE management appears to be problematic for many Lithuanian households as the share of unbalanced household budgets amounts to $40 \%$ and the share of non-performing loans in retail banking never went below 5.5-6\% since 2009. The situation is even worse in countries, like Greece, Cyprus, Italy, Ireland and many others, which shows that this problem is wide and not restricted to one single country.

Various social, cultural, psychological and other motives having no or almost no relation to economic logics strongly affect the PCE-related decision-making in households. They shape consumption behaviour and form typical consumption patterns, classified by, e.g. social class, human psychology or personality attributes, or by recently emerged consumption habits, like, sustainable consumption, green consumption, smart consumption or connected consumers, etc. 
Performed analysis of scientific literature shows that behaviour within the specific consumer pattern is usually not homogeneous, which further complicates the whole picture and illustrates how complex and difficult is rational consumer decision-making. Efforts to systemise the buying-decision process and develop universal guidelines for rational consumers were not successful so far.

Analysis of currently used PCE management tools shows that although the market is relatively saturated with various models, none of them help the consumer with rational distribution of funds among goods/services prior to their purchase. As total consumption budget of the household is composed of elementary purchases, the budget soundness is first of all subject to proper allocation of funds for them.

Results of the research revieled that solving PCE management tasks is challenging for many households and they are in need of theoretical support and efficient practical tools. The lack of both is among the main causes of numerous budget management problems in households.

This paper introduces a new system of quantitative criteria for evaluation of consumption alternatives developed by applying an integrated economic-psychological approach for evaluation of goods/services and a vector technique for decomposition of their aggregate value. The aggregate value is being split into vector components, each reflecting a certain level of Maslow's pyramid of needs, and is given a quantitative score having a price dimension. The magnitude of each value component reflects the price which consumer has to pay for this specific component; therefore, decision whether or not to buy the extra value can be made based on objective and quantitative information.

The paper provides mathematical expressions for: 1) matchmaking between the good and the consumer's needs by calculating spatial angle between the vectors representing consumer preferences and the aggregate value of the good; 2) calculation of aggregate value, when its components are known, and 3) calculation of value component magnitudes when certain market price information is available on the good alternatives.

The introduced principles of expenditure control can be used by households for budget planning and allocation of financial resources for every elementary purchase in a way that is free from the influence of subjective psychological factors.

Several case studies have been performed to verify the applicability and efficiency of introduced criteria. The results from performed study within nourishment confirm that their application enables refinement and quantification of value components as well as evaluation and comparison of consumption alternatives as a final goal.

\section{References}

Alvarez-Quadrado, F.; Japaridze, I. 2017. Tricle-down consumption, financial deregulation, inequality, and indebtedness, Journal of Economic Behaviour \& Organization 134: 1-26. https://doi.org/10.1016/j.jebo.2016.12.007

Arnold, J.; Randall, R.; Patterson, F.; Silvester, J.; Robertson, I.; Cooper, C.; Burnes, B.; Harris, D.; Axtell, C.; Hartog, D. D. 2010. Work psychology: understanding human behaviour in the workplace. 5th ed. London: Pitman. 
Bank of Lithuania. 2015. An overview of household survey on financial behaviour [online], [cited 22 November 2015]. Available from Internet: http://www.lb.lt/namu_ukiu_finansines_ elgsenos_apklausos_apzvalga_2015_nr_1_2.

Bank of Lithuania. 2016. Review of banking performance in 2015 [online], [cited 22 November 2015]. Available from Internet: http://www.lb.lt/banku_apzvalga_2015_m_iv_ketvirtis

Becker, G. S. 1960. An economic analysis of fertility, Demographic and Economic Change in Developed Countries (1): 209-240.

Bertrand, M.; Morse, A. 2016. Tricle-down consumption, The Review of Economics and Statistics 98(5): 863-879. https://doi.org/10.1162/REST_a_00613

Bray, J. 2008. Consumer behaviour theory: approaches and models [online], [cited 10 October 2015]. Available from Internet: http://eprints.bournemouth.ac.uk/10107/1/Consumer Behaviour_Theory_-_Approaches_\%26_Models.pdf.

Brohmann, B.; Quack, D. 2015. Smart consumption: buying with a view to sustainable benefits [online], [cited 10 October 2015]. Institute for Applied Ecology. Available from Internet: http:// www.oeko.de/en/research-consultancy/issues/sustainable-consumption/smart-consumption.

Connoly, J.; Prothero, A. 2008. Green consumption: life-politics, risk and contradictions, Journal of Consumer Culture 8(1): 117-145. https://doi.org/10.1177/1469540507086422

Consiglio, A.; Cocco, F.; Zenios, S. A. 2002. Personal asset allocation. Working Paper in HERMES Center of Excellence on Computational Finance \& Economics, School of Economics and Management, University of Cyprus.

Consiglio, A.; Cocco, F.; Zenios, S. A. 2007. Scenario optimization asset and liability modelling for individual investors, Annals of Operations Research 152: 167-191.

https://doi.org/10.1007/s10479-006-0133-5

Consumer Voice Organization. 2012. Factors influencing consumer behavior [online], [cited 21 July 2014]. Available from Internet: https://consumervoiceblog.wordpress.com/2012/08/03/ factors-influencing-consumer-behaviour/.

Corpuz, J. 2015. 10 best budgeting and personal finance apps [online], [cited 17 August 2015]. Available from Internet: http://www.tomsguide.com/us/pictures-story/548-best-budget-expenseapps.html

Crary, M. 2012. Budgeting software options [online], [cited 13 November 2012]. Available from Internet: http://www.forbes.com/sites/moneywisewomen/2012/01/03/budgeting-software-options/ \#2ff46be3218f.

Czech, A. 2012. Methodological aspects of consumption research in direct analysis, Economics and Management 4(4): 7-17.

Dasgupta, S.; Papadimitriou, C. H.; Vazirani, U. V. 2006. Algorithms [online], [cited 24 February 2013], 161-181. Available from Internet: https://www.cs.berkeley.edu/ vazirani/algorithms/ chap6.pdf). ISBN-13: 978-0073523408.

Dean, M. 2009. Consumer Theory. In: Lecture Notes for Fall 2009 Introductory Microeconomics. Brown University.

Deaton, A. 1992. Understanding consumption. Oxford University Press.

https://doi.org/10.1093/0198288247.001.0001

Dempster, M. A. H.; Medova, E. A. 2011. Asset liability management for individual households, British Actuarial Journal 16(2): 405-439. https://doi.org/10.1017/S135732171100016X

Denardo, E. V. 2003. Dynamic programming: models and applications. Mineola, NY: Dover Publications.

Elliott, R. 2013. The taste for green: the possibilities and dynamics of status differentiation through "green" consumption, Sci Verse ScienceDirect 41(3): 294-322.

https://doi.org/10.1016/j.poetic.2013.03.003 
Engel, J. F.; Kollat D. T.; Blackwell, R. D. 1968. Consumer behavior. New York.

Euromonitor International. 2015. 7 consumer types for successful targeted marketing [online], [cited 22 October 2015]. Available from Internet: http://go.euromonitor.com/white-paper-7-consumer-types-for-successful-targeted-marketing.html.

Freud, S. 1904. Psychopathology of everyday life. Berlin, Germany.

Friedman, M. A. 1957. Theory of the consumption function [online], [cited 22 October 2015]. EconPapers. Available from Internet: http://econpapers.repec.org/bookchap/nbrnberbk/frie57-1. htm.

Foxall, G. 1990. Consumer psychology in behavioural perspective. London: Routledge.

Ganong, P.; Noel, P. 2016. Consumer spending during unemployment: positive and normative implications [online], [cited 20 February2017]. Available from Internet: https://scholar.harvard. edu/files/ganong/files/ganong_jmp_unemployment_spending.pdf.

Ginevičius, R.; Podvezko, V. 2008. A feasibility study of multi-criteria methods' application to quantitative evaluation of social phenomena, Business: Theory and Practice 9(2): 81-87. https://doi.org/10.3846/1392-8619.2009.15.418-436

Ginevičius, R.; Podvezko, V. 2007. Some problems of evaluating multicriteria decision methods, International Journal of Management and Decision Making 8(5/6): 527-539.

https://doi.org/10.1504/IJMDM.2007.013415

Hardardottir, H. 2017. Long term stability of time preferences and the role of the macroeconomic situation, Journal of Economic Psychology (in press) https://doi.org/10.1016/j.joep.2016.12.006 Henry, A. 2014. Five best personal finance tools [online], [cited 26 March 2014]. Available from Internet: http://lifehacker.com/5828438/five-best-desktop-personal-finance-tools.

Herdrich, K. 2008. Household budget management: top online tools [online], [cited 12 September 2015]. Available from Internet: http://www.womansday.com/life/work-money/tips/a3892/ household-budget-management-top-online-tools-78082/.

Hertwich, E. G.; Gibon, T.; Bouman, E.; Arvesen, A.; Suh, S.; Heath, G.; Bergesen, J.; Ramirez, A.; Vega, M.; Shi, L. 2015. Integrated life-cycle assessment of electricity-supply scenarios confirms global environmental benefit of low-carbon technologies, Proceedings of the National Academy of Sciences of the United States of America 112(20): 6277-6282.

https://doi.org/10.1073/pnas.1312753111

Hocht, S.; Hwa, N. K.; Rosch, C. G.; Zagst, R. 2008. Asset liability management in financial planning, The Journal of Wealth Management 11(2): 29-46. https://doi.org/10.3905/jwm.11.2.29 Howard, J. A.; Sheth, J. N. 1969. The theory of buyer behavior. New York: Wiley.

Kahneman, D.; Tversky, A. 1979. Prospect theory: an analysis of decision under risk, Econometrica 47(2): 263-291. https://doi.org/10.2307/1914185

Konicz, A. K. 2012. A hybrid model for optimal decisions within personal finance and retirement. OR Seminar, Technical University of Denmark, Department of Technical Engineering.

Kyrk, H. 1923. A Theory of Consumption. Boston: Houghton Mifflin.

Lancaster, K. 1966. A new approach to consumer theory, Journal of Political Economy 74(2): 132-157. https://doi.org/10.1086/259131

Maslow, A. H. 1954. Motivation and personality. New York, NY: Harper.

Oracle. 2012. The connected consumer: evolving behavior patterns. A consumer research study [online], [cited 01 October 2015]. Available from Internet: www.oracle.com/us/.../retail/researchconnected-consumer-1736894.pdf

Parker, J. 2010. 16 Theories of consumption and saving. Economics 314 Courcebook. 16-24.

Pedersen, A. M. B.; Weissensteiner, A.; Poulsen, R. 2013. Financial planning for young households, Annals of Operations Research 205(1): 55-76. https://doi.org/10.1007/s10479-012-1205-3 
Persky, J. 1995. The ethology of homo economicus, The Journal of Economic Perspectives 9(2): 221-231. https://doi.org/10.1257/jep.9.2.221

Pollak, R. A. 2002. Gary Becker's contributions to family and household economics, Review of Economics of the Household 1(1): 111-141. https://doi.org/10.1023/A:1021803615737

Quintana-Domeque, C.; Wohlfart, J. 2016. Relative concerns for consumption of the top: an intertemporal analysis for the UK, Journal of Economic Behaviour \& Organization 129: 172-194. https://doi.org/10.1016/j.jebo.2016.06.005

Richarme, M. 2005. Consumer decision making-models, strategies and theories, Decision Analyst 1: $1-3$.

Rose, J. 2016. Ready to start investing? The best online brokers for beginners [online], [cited 26 January 2016]. Available from Internet: http://www.goodfinancialcents.com/best-online-stockbrokers-for-beginners-small-investors/.

Rose, J. 2012. The 11 best personal finance software to get your money swag on [online], [cited 27 April 2015]. Available from Internet: http://www.goodfinancialcents.com/best-personalfinance-software-free-to-download/.

Sage. 2016. Prospero asset management software [online], [cited 12 November 2015]. Available from Internet: http://www.sage.ch/products/prospero-asset-management/?gclid=CjwKEAiAmY3BRDh7pjvg46p1iYSJADQ78gNacGjUrolaPzJSEYEdWo1hkNPGq5KFG5ZBf4gYtEwJRoCG Y_w_wcB.

Simon, H. 1997. Administrative behavior: a study of decision-making processes in administrative organizations. 4th ed. New York: The Free Press.

Sharf, S. 2016. 12 free apps to track your spending and how to pick the best one for you [online], [cited 23 July 2015]. Available from Internet: http://www.forbes.com/sites/samanthasharf/ 2016/03/02/12-free-apps-to-track-your-spending-and-how-to-pick-the-best-one-foryou/\#282c8ff52b69.

Smith, N. R. 1964. Consumer behavior patterns, Journal of Extension 2(1): 45-53.

Sniedovich, M. 2010. Dynamic programming: foundations and principles. Taylor \& Francis. https://doi.org/10.1201/EBK0824740993

Stewart, J. 1994. The psychology of decision making, in D. Jennings, S. Wattam (Eds.). Decision making: an integrated approach. London: Pitman.

Ribeaux, P.; Poppleton, S. E. 1978. Psychology and work. London: Macmillan Education.

Taujanskaitè, K.; Milčius, E. 2012. Impact of financial crisis on Lithuanian households' ability to manage budgets, in 7th International Scientific Conference "Business and Management 2012", 10-11 May 2012, Vilnius, Lithuania.

Taujanskaite, K.; Milčius, E. 2015. Management of household expenditure by using value decomposition technique, in 1st International Conference on Business Management, 2-3 July 2015, Valencia, Spain. Universitat Politècnica de València.

Taujanskaitè, K.; Milčius, E.; Rutkauskas, A. V. 2015. Integrated cross disciplinary approach to household expenditure management, Engineering Economics 26(5): 489-499.

https://doi.org/10.5755/j01.ee.26.5.13066

World Bank. 2016. Household final consumption expenditure [online], [cited 16 January 2016]. Available from Internet: http://data.worldbank.org/indicator/NE.CON.PETC.ZS/countries? display=map.

Ziemba, W. T.; Mulvey, J. M. 1998. Worldwide asset and liability modelling. Cambridge: Cambridge University Press.

Zhao, Q.; Li, Z.; Chen, T. 2016. The impact of public pension of household consumption: evidence from China's survey data, Sustainability 8(890): 1-15. https://doi.org/10.3390/su8090890 
Kamilė TAUJANSKAITÉ is a Vice-Dean of Business and Management Faculty in Vilnius Gediminas Technical University and a lecturer in Department of Finance Engineering. She is a $\mathrm{PhD}$ of Economics. Till the end of 2014 she took credit administrator's position in a commercial bank operating in Lithuania and gained experience in credit risk management, non-performing loans portfolio management and insolvent debtors' financial condition evaluation. Her research interests include: personal finance management, household economics, consumption expenditure management, consumption-related decision-making, personal insolvency and etc.

Eugenijus MILČIUS, PhD in technology science, 1984. Research fellow at Faculty of Mechanical Engineering and Design of Kaunas University of Technology. Research interests: electrical drives operating in ultra-deep (up to $12 \mathrm{~km}$ and more) boreholes used for Earth's crust research - years 1974-1994; business development consultant - years 1994-2004, including 6 years at Confederation of Danish Industries; from 2004 - innovation economics within the field of packaging technology.

Nomeda DOBROVOLSKIENĖ PhD, is a Lecturer of the Department of Finance Engineering, Faculty of Business Management, Vilnius Gediminas Technical University, Lithuania. Hers research interests focus on projects, project portfolio, project portfolio management, sustainability. 